\title{
Photographers Hart, Campbell and Company: The role of photography in exploration, tourism and national promotion in nineteenth century New Zealand.
}

Alan Cocker

Keywords \# Hart, Campbell \# national promotion \# photography and exploration \# picturesque \# Frontier thesis \# savage grandeur It has been argued that "the history of New Zealand is unique because the period of pioneer colonization closely coincided with the invention and development of photography"1. However, as the first successfully recorded photograph in the country was not made until the late 1840s, the widespread use of photography came after the initial European settlement and its influence coincided more closely with the development of early tourism and with the exploration and later promotion of the country's wild and remote places. The photographic partnership of William Hart and Charles Campbell followed the path of the gold miners into the hinterland of the South Island aware of its potential commercial photographic value. Photographers understood the "great public interest in what the colony looked like and in the potential for features that would command international attention" ${ }^{\prime 2}$. Photography was promoted as presenting the world as it was, free of the interpretation of the artist. By the early 1880 s the Hart, Campbell portfolio was extensive and their work featured at exhibitions in London, Sydney and Melbourne. Yet their photographs were criticised for fakery and William Hart's photograph of Sutherland Falls, 'the world's highest waterfall', promoted a quite inaccurate claim. 
By the 1870s, when William Hart and Charles Campbell became active as photographers of the landscapes of Otago and Southland, photographs were held to have clear advantages over other forms of visual depiction such as the painting, watercolour or sketch. In Photography and Exploration James Ryan quotes the nineteenth century writer Gaston Tissandier on the photograph: "no one can deny their accuracy. A photograph represents an object just as it is.... Nothing is deficient in the print. A painting or a watercolour can never have such rigorous precision". ${ }^{3}$

For Hart and Campbell the landscape photographs they took were part of a quest to cater to a growing market for dramatic landscape views both within New Zealand and internationally. For the New Zealand colonist it has been argued that the acts of surveying and photographing were part of colonisation attaching "a possessable image to a place name. A named view is one that has been seen, known, and thereby already possessed"4. But the images could also be a source of pride for the settler, their new land was blessed in its beauty, and they could proudly send back photographs of it to their relatives in their home countries. Drawing on ideas of the picturesque ${ }^{5}$, first formulated by mid-eighteenth century artists capturing England's Peak and Lake Districts, the photographers of New Zealand's wilder regions also sought to depict "a more savage grandeur"6 an evocation of the sublime where there is awe and reverence of nature at its most fearsome.

In identifying a common language of landscape representation in New Zealand and California in the nineteenth century, Schenker argues that painters and photographers forged cultural identities "using images of 'nature' and the 'natural' landscape". ? Those who seem to have that common language would be photographers like Alfred Burton and the Hart and Campbell partnership in New Zealand and Carleton Watkins, William Henry Jackson and Eadweard Muybridge in California. Schenker believes that the landscapes of both places were appropriated as an emblem of national identity, the lands being seen as 'natural wonders' with paintings and photographs serving to make exotic places familiar, accessible and consumable. Painters and photographers "evoked the sublime by means of a repertoire of established compositional formulae" ${ }^{\prime \prime}$.

Rod Gilbert argues that photographs of wilderness areas and national parks "have been crucial for the formation and maintenance of national identity" . The early European settlers in the United States and New Zealand regarded the land as a spiritual and physical void which had to be tamed and civilised in the name of progress. However,

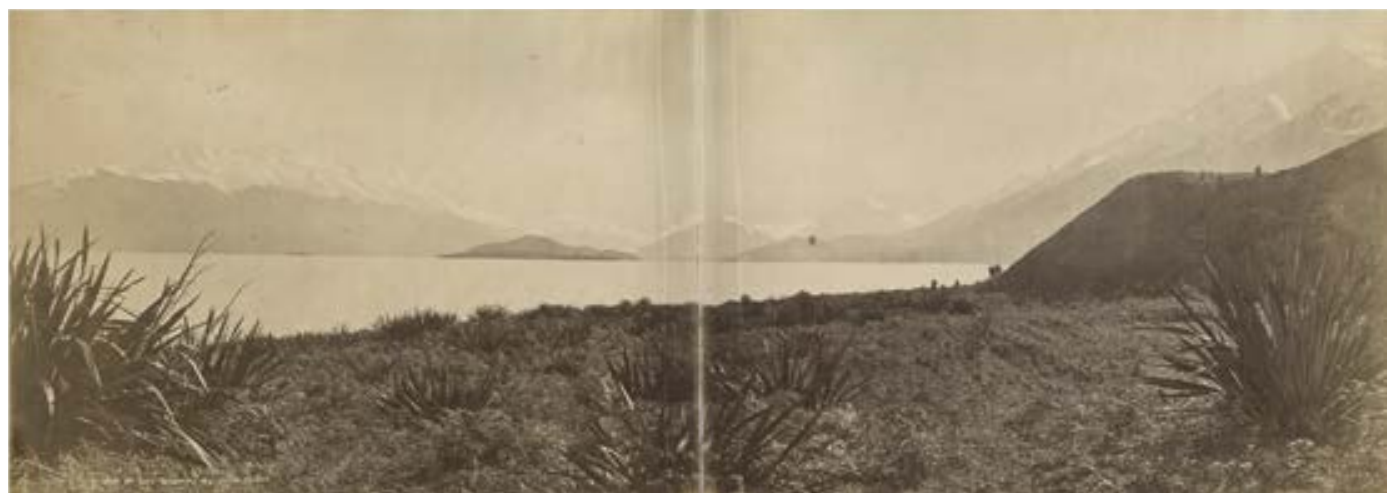

Figure 1: Image entitled 'head of Lake Whakatipu from 26 mile' by Hart, Campbell \& Co. Collection of the author.

by the later nineteenth century there were signs that these attitudes were being countered by changed perceptions of the natural world in these countries. In 1893, Frederick Jackson Turner was to propound his 'Frontier Thesis' in the United States. He argued that: "American democracy...came out of the American forest $t^{10 "}$ and it gained new strength each time it touched a frontier.

By the 1870s, European exploration had opened up more remote parts of New Zealand for the traveller. Steam ship companies began to advertise trips for tourists to New Zealand and printed guidebooks for their instruction. Writer Thomas Bracken set the scene in a publication entitled The New Zealand Tourist for the Union Steam Ship Company in 1879: "Until a few years back, New Zealand was a terra incognito to the great mass of mankind, and even now there are comparatively few persons living out of the Colony itself who have anything but the very faintest conception of the marvellous magnificence of this peerless land"." Bracken, who was to later pen the words for the country's national anthem, claimed that the "romantic character of our New Zealand scenery is not surpassed in any other portion of the world". ${ }^{12}$

In presenting New Zealand to the world, James Hector, the Director of the country's Colonial Museum, felt that only photographs could adequately represent the country at the Vienna Exhibition of 1873 and the Philadelphia Exhibition of 1876. Rice states that Hector was "not just interested in the aesthetic appeal of photographs but saw them as having the capacity to enhance the educational aspect of the exhibits ${ }^{\prime \prime 3}$. It was felt that photography enabled audiences to view with a new and unprecedented truthfulness the wonders of the world. 


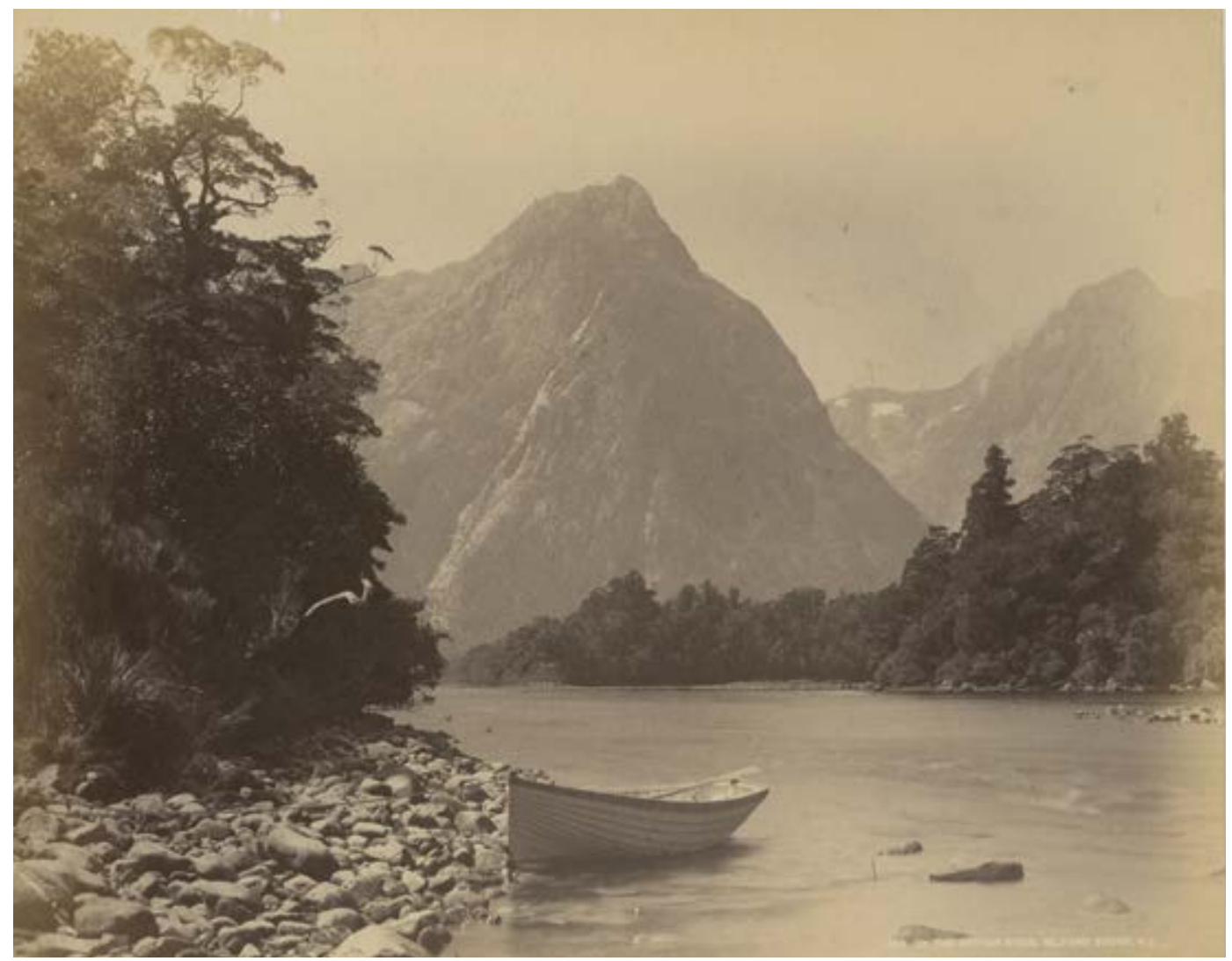

Figure 2: Image entitled 'On the Arthur River, Milford Sound, N.Z.' by Hart, Campbell \& Co. Collection of the author.

Dunedin was the home of the largest photographic studios in the mid to late 1800 s and many photographers learnt their trade working for these studios. William Hart began as a photographer with Clifford \& Morris whilst Charles Campbell stated that he had a nine year relationship with the Burton Brothers. ${ }^{14}$ Both Hart and Campbell were born in Scotland and arrived as boys in New Zealand, Hart aged ten in 1856, and Campbell when he was eight years old in $1863^{15}$. According to New Zealand photographic historian Hardwicke Knight, as a young man Hart joined the gold rush and worked as a miner in Central Otago. Apparently unsuccessful in this quest he worked in a store in Arrowtown before taking up photography in the mid-1870s. He also had a reputation as a cross-country runner and long distance walker, attributes that would assist him in carrying his camera equipment into the mountains of New Zealand's South Island. ${ }^{16}$ As Campbell claims in 1876 to have already served nine years with the Burton studio, he must have joined them as a teenage apprentice.
From 1876 to 1889 Hart and Campbell were in partnership based in the southern city of Invercargill as Hart, Campbell and Company. After the two partners initially undertook a photographic tour through the region capturing gold mining activity, the new sheep stations and scenic views ${ }^{17}$; Campbell appears to have spent most the rest of the partnership in the Invercargill studio whilst Hart undertook a more peripatetic existence as a landscape photographer. Mitchell writes that: "Geographically remote landscape features were a marketable subject for nineteenth century photographers". ${ }^{18}$

Hart, Campbell and Company sent examples of their views to the Sydney and Melbourne Exhibitions of 1880. Twenty-five photographs of scenes of the 'Lakes District' of the South Island were exhibited by them in Melbourne ${ }^{19}$ and in Sydney they were awarded a certificate and second position amongst New Zealand competitors for their selection ${ }^{20}$. A correspondent for the Otago Witness newspaper ${ }^{21}$ reported that over the past season there had been a great influx of visitors to the Lake District and that "many of the tourists stated that they were induced to make the trip by the views of Lake Whakatip (sic) scenery exhibited by Messrs Hart, Campbell and Co at the Sydney Exhibition". However, at a subsequent exhibition of their photographs in Dunedin in 1881 they were accused of 'faking' because they introduced certain effects, such as moonlight, into their images. A writer in their defence argued that it was "pretty well known by those who take any interest in photographic work that all negatives are now modelled and manipulated"22. The correspondent further felt that it was well-known that moonlight photography was not yet possible and no one could be deceived into believing that the night effects were natural and not the result of clever manipulation. Another report in the same newspaper two months late ${ }^{23}$ stated that criticism did not take into account "the wintry aspect and evident elevations at which several of the negatives have been secured" which suggested "a good deal of hardship endured by the artist" and it had to be "conceded that the work of converting day into night had been most cleverly done".

In capturing 'new landscapes' of places largely unknown to the European world, photographers sought to combine scientific discovery and objectivity with the desire to create a pleasing picture conforming to conventions of landscape beauty. Ryan states that despite the tendency among twentieth-century historians of photography to separate 'scientific' from 'artistic' photography, these domains were never entirely distinct and in its early days photography was commonly referred to as an 'Art-Science ${ }^{24}$. He quotes the nineteenth-century 


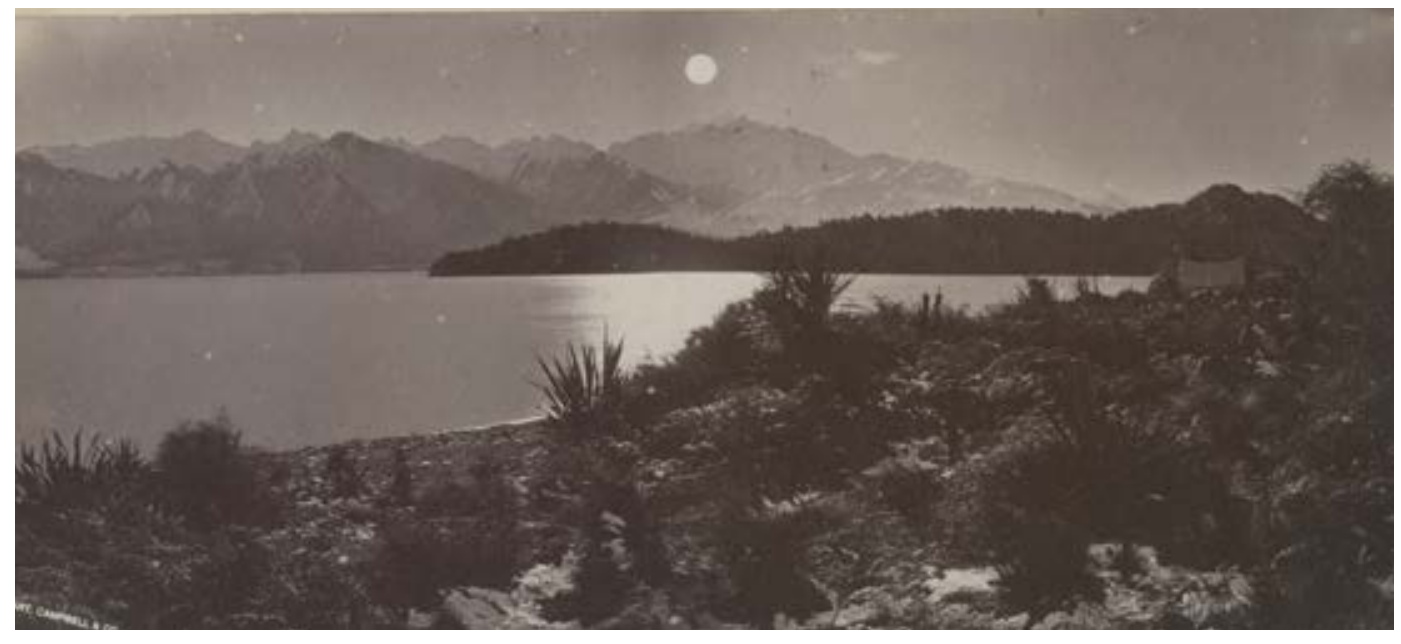

Figure 3: Image entitled 'Moonlight over Lake Hawea' by Hart, Campbell \& Co. Collection of the author. On the print the moon has been clearly 'painted in'.

soldier and photographer William Abney who wrote in his popular photographic instruction book of 1871 (Instruction in Photography):

"To become a good photographer...it is necessary to turn to it with an artistic and scientific mind". ${ }^{25}$

For Hart and Campbell the foremost consideration was sale in a commercial market. The government saw the virtue in the photographs for the promotion of tourism, for the understanding of the country's geography and cultural identity but the photographers did not have the benefit of any public funding for their work. It is therefore understandable that they would focus on those aspects of any scene which might enhance an image's saleability. Certainly the claim of a breakthrough in photographic art, the capturing of a scene in moonlight, would attract the interest of the consumer of landscape views. Notions of the sublime in landscape art also pushed photographers and artists to seek ever more dramatic scenes, or what has been described as 'savage grandeur' 26 .

Perhaps the perfect example of this dramatic subject matter was furnished by Donald Sutherland. In November 1877, Sutherland, a Scottish adventurer with a colourful background which had included fighting as a volunteer for Garibaldi's Italian patriots, set sail in a small boat from the southern city of Dunedin for the remote West Coast of the South Island ${ }^{27}$. On the 3rd of December he landed at Milford Sound and after an unsuccessful period prospecting, he turned to exploring in the hope of discovering an inland route to Queenstown and thus creating an overland link between the east and west coasts of southern New Zealand. During this exploration he discovered on the 10 November 1880 what he believed to be the world's highest waterfall.

News of Sutherland's discovery attracted surveyors,

prospectors, artists and photographers. William Hart travelled into Milford Sound, Fiordland in February 1883 in the company of fellow photographers Alfred Burton and Fred Edwards ${ }^{28}$ and painter, Francis Huddlestone ${ }^{29}$ where they joined Samuel Moreton, an English artist who had come from Australia to, in his own words, "add a valuable stock of sketches" to his portfolio ${ }^{30}$. Milford and Fiordland were believed to offer scenery that far surpassed anything in Switzerland. The camera would be important in alerting the traveller "well-schooled in landscape aesthetics" ${ }^{\prime \prime 1}$. The prime attraction, however, was the waterfall which promised the ultimate in 'sublime' natural scenery.

The practical difficulties of carrying photographic gear into the largely trackless terrain were daunting. Fabian and Adam characterise the problems encountered by the nineteenth century travelling photographer: "The early photographer's journey was ...considered an 'expedition', his machine a 'travelling camera', and the actual taking of the photographs an 'operation'". ${ }^{32}$ When Hart journeyed into New Zealand's Fiordland "pack animals do not appear to have been an option for traversing the steep landscape at Milford Sound and there was nowhere for ships to land". ${ }^{33}$ Thus photographers had to carry their own equipment or rely on others for help.

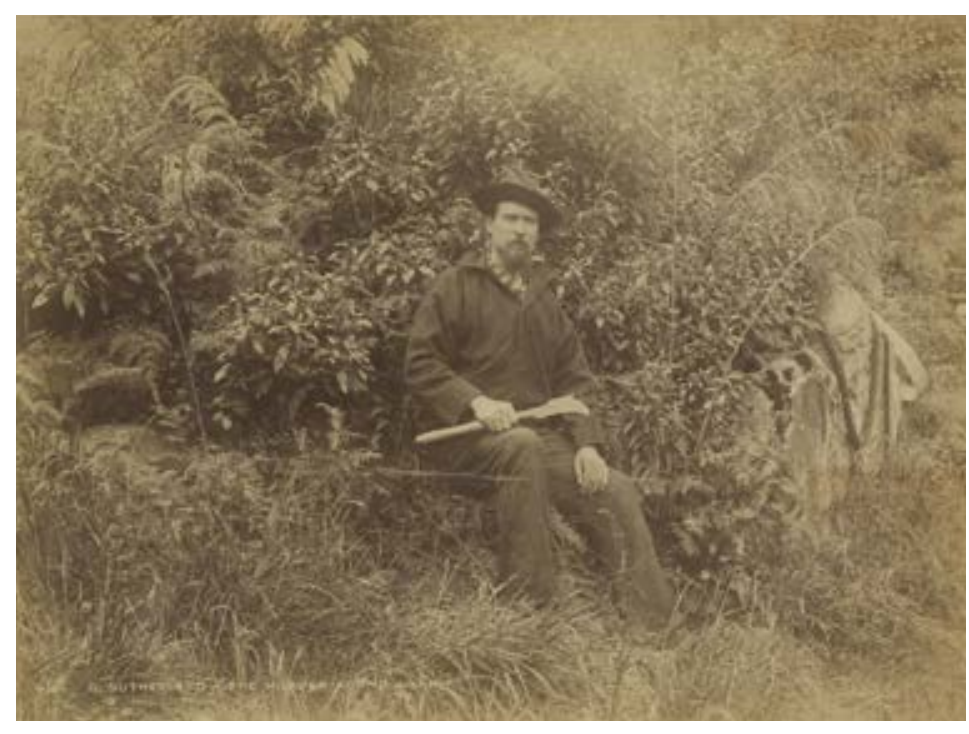

Figure 4: Image entitled D.Sutherland - "The Milford Sound Hermit". Photo has Burton Bros. number. Collection of the author. 
The utility and practicality of photography was steadily improved by technical developments. Particularly the advent of dry plates and the greater light sensitivity of the gelatine-bromide process in the $1870 \mathrm{~s}$, and later the advent of celluloid 'roll film' in the 1880s. In part, states Ryan ${ }^{34}$, the history of the interaction between photography and exploration is a story of changing technology. After the introduction of dry plates the Royal Geographical Society was encouraging explorers to adopt the medium because this new process allowed photographs to be taken everywhere and anywhere ${ }^{35}$. Hart and Campbell announced in August $1882^{36}$ that they had been using a gelatine emulsion and dry plate process for upwards of twelve months which would indicate that William Hart had the ability to work with a dry plate process in Fiordland although Mitchell states that "Hart was one of New Zealand's most artistically assured photographers with the wet plate collodion process" and that he continued to use it long after other photographers had changed to dry plate. ${ }^{37}$

Although three photographers and two artists had gathered with their equipment at Milford Sound in February 1883, only William Hart and Samuel Moreton would accompany Donald Sutherland on an expedition to the 'world's highest falls'. Alfred Burton, of the established Burton Brothers photography studio had visited Milford Sound before and the previous year had been thwarted in the attempt to accompany Sutherland to the falls by bad weather. According to Moreton for this expedition he had "provisions and paraphernalia...as much as all the rest put together" and he believed this was an unfair burden on the other members of the party. ${ }^{38}$ But Moreton further argued that Burton the oldest in the party, was not fit enough to make the trip and he deliberately contrived to sabotage Burton's participation by hiding a canoe which the expedition needed as part of their journey. Once Burton, Huddlestone and Edwards had left Milford Sound by steamer, Sutherland, Hart and Moreton set out and successfully reached the falls in four days. Moreton seeks to justify his actions by saying that even though Hart was an athlete:

"...towards the end of the journey down he frequently referred to the fact that upon no consideration would he think of facing the same journey. The fatigue that was undergone was beyond, and could never be described; many a time I had to go and rescue Hart, who had broken through and was forked by both legs and fixed, and had to be lifted bodily upward, swag and all. And when I compare the two men - viz. Hart and Burton - instead of the latter heaping on his satirical abuse, he should fall on his bended knees and thank God for saving him to his family". ${ }^{39}$

Although they reached the falls Hart's problems were not over. Again in Moreton's account the photographer "could not make pictures, on account of the nearness and tremendousness of the surroundings", so in order to capture the falls at all the party had to retire some two miles from it. The image Hart took does very little justice to what was intended to be a sublime landscape scene. It shows only the top part of the falls above the tree line whilst in the foreground artist Samuel Moreton is sketching beside the expedition's tent (Figure 5). Even technically the image has issues with Moreton's face blurred, presumably as he had moved his head during the exposure. It seems a meagre return for such an arduous undertaking to 'the world's highest waterfall'.

The photograph which was meant to be an exact representation of reality, also perpetuates a myth. Sutherland had estimated the height of Sutherland Falls, named by Hart ${ }^{40}$ after their discoverer, at 5,700 feet. This would have made them the highest falls in the world. However by its nature Hart's photograph disguises any attempt to verify this. It would be another six years (October 1888) before a party of surveyors led by Otago Province's Chief Surveyor,

C.W. Adams, accompanied by photographers, including Alfred Burton,

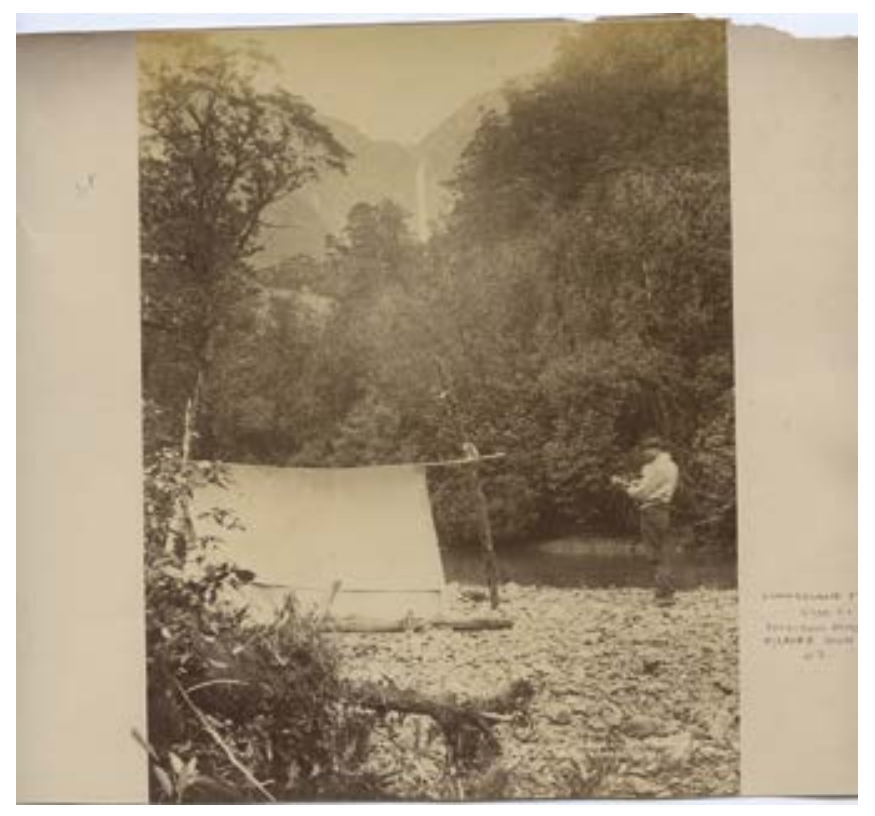

ure Entitled 'Sutherland Falls, $5,700 \mathrm{ft}$., Poseidon River, Milford Sound, New Zealand by Hart, Campbell \& Co. Collection of the author. 
estimated that the waterfall was 1,904 ft. high. A year later surveyor William Quill ascended Sutherland Fall and confirmed this height. His report to Adams stated: "The Sutherland Falls is $1904 \mathrm{ft}$ high, and strikes the rocky precipice twice in its descent, forming three leaps, the upper being $815 \mathrm{ft}$, the middle on $751 \mathrm{ft}$, and the lower $338 \mathrm{ft}^{\prime \prime} .{ }^{41}$

Thus the original claim for the height of Sutherland Falls was nearly three times their actual height. As Mitchell points out ${ }^{42}$ whether Sutherland consciously exaggerated the height is unknown but if it was a profitable attraction for the area it would help his recognition as an explorer and gain financial assistance for his work. For Hart it would have made commercial sense to repeat the claim on his photograph that the falls were 5,700ft. Therefore, he had been the first to capture an image of the world's highest waterfall. Despite Quill's measurements showing Sutherland Falls to be only the seventh highest, postcards continued to be printed claiming it was 'the highest waterfall in the world' into the early twentieth century. ${ }^{43}$

It is recounted that photography was the child of a desire to bring home in visual form an unequivocal description of wonders seen. ${ }^{44}$ Fox Talbot was sketching on the shores of Lake Como in Italy when he was saddened that his artistic ability was not up to the task of faithfully recording what he was seeing. He resolved to investigate whether it would be "possible to cause these natural images to imprint themselves durably and remain fixed upon the paper ${ }^{\prime \prime 45}$. However, the medium he helped to create would not be the unproblematic 'pencil of nature'. The photographic views of William Hart and Charles Campbell were used to attract travellers to New Zealand and record the discovery of 'sublime' natural phenomena. However, their view of the world was coloured by commercial imperatives and this could lead them to present day as night or perpetuate a myth about the world's highest waterfall. Their photographs were not exact scientific records; art, and particularly, commerce, appear to have been the more important considerations for these photographers.

\section{REFERENCES}

Bracken, Thomas. The New Zealand Tourist. Dunedin: The Union Steam Ship Company, 1879

Fabian, Rainer \& Hans-Christian Adam. Masters of Early Travel Photography. London: Thames and Hudson, 1983.

Gilbert, Rod. Landscapes of Culture and Nature. Palgrave Macmillan: Basingstoke, 2009.

John, D.H.O. Photography on Expeditions. London: Focal Press, 1965

Hannavy, John (ed.). Encyclopaedia of Nineteenth-Century Photography, Vol. 1. New York: Routledge, 2008.

Knight, Hardwicke. Photography in New Zealand: A Social and Technical History. Dunedin: John Mclndoe, 1971.

Knight, Hardwicke. "Hart, William Paterson $(1845-1926) "$ ", in Southern people: A Dictionary of Otago Southland Biography, Jane Thomson, ed. Dunedin: Longacre Press in association with the Dunedin City Council, 1998: 214.

Mitchell, Lissa. "Photographing Sutherland Falls", in the New Zealand Journal of Photography 63, (2009): 16-21.

Rice, Rebecca. "The Art of Photography at Nineteenth Century International Exhibitions", in the New Zealand Journal of Photography 63, (2007):
Ryan, James R. Photography and Exploration. London: Reaktion, 2013.

Schenker, Heath. "A Common Language of Landscape Representation: New Zealand and California Painting in the Nineteenth Century", in Landscape Review, 2, (1995): 42-55.

Thompson, T. Jack. Images of Africa: Missionary Photography in the Nineteenth Century: An Introduction. Copenhagen: Occasional paper published by the Centre of African Studies, University of Copenhagen, (2004).

Tong, Benson and Regan A. Lutz (eds.) The Human Tradition in the American West. Lanham: Rowman \& Littlefield, 2001

Wevers, Lydia. "The Pleasure of Walking", in the New Zealand Journal of History, 38, No.1 (2004): 39-51.

Whybrew, Christine. (2011) "'Reading' Photographs: Burton Brothers and the Photographic Narrative", in The Journal of New Zealand Studies, No.12 (2011): 77-89. 


\section{ENDNOTES}

1 This claim is made by Hardwicke Knight in his 1971 book Photography in New Zealand: A Social and Technical History, p.9.

2 Lissa Mitchell 'Photographing Sutherland Falls' in the New Zealand Journal of Photography No. 63, p.16.

3 In James Ryan, Photography and Exploration p. 13.

4 The quote is from Alan Trachtenberg, Reading American Photographs: Images as History, Matthew Brady to Walker Evans, New York, 1989, p.125. Christine Whybrew in 'Reading' Photographs: Burton Brothers and the Photographic Narrative, The Journal of New Zealand Studies, No.12 (2011), pp.77-90, quotes Trachtenberg and Giselle Byrnes, Boundary Markers: Land Surveying and the Colonisation of New Zealand, Wellington, 2001, pp.5-6; to make the point that photography was part of the colonial process of identifying and possessing the land.

5 The concept of the 'picturesque' was one of three aesthetic concepts established during the romantic era which divided the natural world into categories, the other two were the 'pastoral' and the 'sublime'. The 'pastoral' and 'picturesque' depicted a comforting and tamed nature. William Gilpin in his Three Essays: On picturesque beauty; on picturesque travel; and on sketching landscape printed in London in 1792, described the 'picturesque' as landscape in its natural state. The 'sublime', however, was untamed nature. Quoted from Heath Schenker, 'A common language of

landscape representation: New Zealand and California painting in the nineteenth century', p. 44.

6 James Ryan, Photography and Exploration, p. 91.

7 Heath Schenker, 'A common language of landscape representation: New Zealand and California painting in the nineteenth century', p.43.

8 See p.820 of the Encyclopaedia of Nineteenth-Century Photography, Vol. 1 edited by John Hannavy.

9 P.11 in Rod Gilbert, Landscapes of Culture and Nature. Palgrave Macmillan: Basingstoke, 2009.

10 See p.xiv in Benson Tong and Regan A. Lutz (eds.). The Human Tradition in the American West.

11 Thomas Bracken writing in The New Zealand Tourist in 1879, p.vi

12 Ibid, p.vii.

13 Rebecca Rice, 'The Art of Photography at nineteenth century international exhibitions' p.10.

14 This information comes from an advertisement Hart and Campbell placed in the Lake County Press (3 May 1876, p.1) soon after the formation of their partnership. They were offering their services to the 'inhabitants of Arrowtown and surrounding District' as portrait and landscape photographers.

15 Charles Campbell's Death Certificate records his birthplace as Moffat Scotland and the number of years he had resided in New Zealand. William Paterson Hart was born on Zealand. 1846 at Pais 4 . the 4 July 1846 at Paisley, Renfrew Scotland. Information from https://family search.org/ ark:/61903/1:1:XTJT-3PV Accessed 24/03/2016. His date of arrival in New Zealand is from Hardwicke Knight. See Endnote 10. Knight does not source this information.

16 This information comes from Hardwicke Knight's short biography of William Hart in Jane Thomson (Editor), Southern People: A Dictionary of Otago Southland Biography published in 1998 by Longacre Press and the Dunedin City Council, p.214. Knight does not give any sources for this information although a search does identify a W.P.Hart competing at the Dunedin Cricket Club Sports in April 1874 in the 120 yards hurdle race (Otago Witness, 25 April, 1874, p.8). There is also Witness, 25 April, 1874, p.8). There is also
evidence of a mining licence being granted to a William Hart on the 3rd of October 1864 at Lawrence, Otago. See: http://www.kaelewis. com/database/prospector.php?database=gold\&query=hart (accessed January 9, 2017)

17 This led to an extensive portfolio of 'views', eighty of which appeared in their photographic album entitled: Gems of Photographic Art. A new series of views of New Zealand's scenery by Hart, Campbell \& Co. Collection of the author.

18 Lissa Mitchell, 'Photographing Sutherland Falls', p.16.

19 As reported in the Southland Times, 24 July,
1880, p. 2

Southland Times, 23 August, 1880 p.2.

21 News report headed 'Lake County', from ou own correspondent, Otago Witness, 3 April 1880 , p.19. The 'great influx' was estimated by the writer to have been about 1,000 travellers.

22 In an article entitled 'Dunedin Industrial Exhibition No.IV', Southland Times, 12 July 1881 p.2.

23 'The Industrial Exhibition, No.9'. Southland imes, 12 September, 1881, p.2.

24 James R. Ryan, (2013) Photography and Exploration, p.78.

25 Ibid.

26 Ibid, p.91. Ryan writes: “While the picturesque presented a safe and agreeable form of beauty...intrepid explorers also sought scenes of a more 'savage grandeur'.

27 See biography by W.T.Parham in the online Te Ara Encyclopedia of New Zealand at http:// www.teara.govt.nz/en/biographies/2s53/ sutherland-donald Accessed 17 November, 2016.

28 Samuel Moreton identified the third photographer as 'Edwards' who worked for the Auckland photography studio of Bartlett and $\mathrm{Co}$. (See correspondence in the Otago Witness, 17 October, 1889, p.9.) Thus the photographer was probably Frederick William Edwards, a photographer who managed Bartlett's studio in Auckland before setting up his own (see http://canterburyphotography.blogspot. co.nz/2012/01/edwards-f-w.html).

29 Francis Fortescue Croft Huddlestone also known as Frank was a surveyor as well as a water colourist. See http://nzetc.victoria. ac.nz/tm/scholarly/tei-PlaNine-t1-bodyancestry.com/ nzlscant/artists.htm

30 See Lydia Wevers, 'The Pleasure of Walking',
2004. p.42.

31 lbid.

32 Rainer Fabian and Hans-Christian Adam. (1983) Masters of Early Travel Photography, p.13

33 Lissa Mitchell, 'Photographing Sutherland Falls', p.17.

34 James R. Ryan, (2013) Photography and Exploration, p.13.

35 lbid.

36 See advertisements in the Southland Times on the 15 August, 1882, p.2 and on $16 \mathrm{Au}-$ gust, 1882, p.2. "Photography - Messrs Hart, Campbell and Co., of Tay Street, elsewhere inform the public that they have been taking photographs by the instantaneous process for the past year or more"

(15 August).

37 Lissa Mitchell, 'Photographing Sutherland Falls', p.20.

38 Alfred Burton, 'Lakeland. Wintering on Lakes Te Anau and Manapouri. A photographer's diary', Otago Witness, 17 October, 1889, p.9. and the response by Samuel H.Moreton in the same issue.

39 lbid.

40 Sutherland in turn named a nearby mountain, Mt. Hart, after the photographer.

41 William Quill, 'Ascent of the Sutherland Waterfall', Oamaru Mail, 24 March 1890, p.4.

42 Lissa Mitchell, 'Photographing Sutherland Falls', p.20.

43 Ibid.

44 D.H.O. John, Photography on Expeditions, p.9). 